\title{
Trace elemental fingerprinting of gastropod statoliths to study larval dispersal trajectories
}

\author{
Danielle C. Zacherl ${ }^{1,2, *}$, Patricio H. Manríquez ${ }^{3}$, Georges Paradis ${ }^{4}$, Robert W. Day ${ }^{5}$, \\ Juan Carlos Castilla ${ }^{3}$, Robert R. Warner ${ }^{1}$, David W. Lea ${ }^{4}$, Steven D. Gaines ${ }^{1}$ \\ ${ }^{1}$ Department of Ecology, Evolution and Marine Biology, University of California, Santa Barbara, California 93106, USA \\ ${ }^{2}$ Department of Organismic Biology, Ecology and Evolution, 621 Charles E. Young Drive South, PO Box 951606, University of California, \\ Los Angeles, California 90095-1606, USA \\ ${ }^{3}$ Estación Costera de Investigaciones Marinas and Departamento de Ecología, Centro para Estudios Abanzados en Ecología y Biodiversidad, \\ Facultad de Ciencias Biológicas, Pontificia Universidad Católica de Chile, Casilla 114-D, Santiago, Chile \\ ${ }^{4}$ Department of Geological Sciences and Marine Science Institute, University of California, Santa Barbara, California 93106, USA \\ ${ }^{5}$ Zoology Department, University of Melbourne, Parkville, Victoria 3010, Australia
}

\begin{abstract}
Larval statoliths of the temperate neogastropod Concholepas concholepas (Bruguière, 1789) appear to have great utility for reconstructing larval dispersal history. Hatching marks on the statoliths seem to demarcate the natal core of recent recruits. Analysis of individual larval statoliths by laser ablation inductively coupled plasma mass spectrometry (LA-ICP-MS) indicates detectable levels of multiple trace elements. Differences in $\mathrm{Ba} / \mathrm{Ca}, \mathrm{Zn} / \mathrm{Ca}$, and $\mathrm{Pb} / \mathrm{Ca}$ in the larval core of $C$. concholepas statoliths from 3 geographically separated sites in Chile suggest these mineralized hard parts could function as natural tags of natal origin and hence be useful in ecological studies of larval dispersal pathways.
\end{abstract}

KEY WORDS: Concholepas concholepas $\cdot$ Larvae $\cdot$ Dispersal · Statolith · Trace elements · LA-ICP-MS

Resale or republication not permitted without written consent of the publisher

Understanding the processes affecting the dispersal and settlement of marine larvae requires the ability to reconstruct their recent history. Where do incoming larvae originate? The answer to this question has farreaching consequences for not only understanding population dynamics and community structure (Caley et al. 1996), but also for the effective management of marine fisheries (Crowder et al. 2000, Warner et al. 2000, Castilla \& Defeo 2001) and the design of marine protected areas (Gaines et al. in press).

Fish biologists have developed an effective tool for reconstructing fish larval dispersal histories by studying the microstructure of the otolith, a balance structure in the inner ear of teleost fishes, that is formed at birth and retained throughout life. Otoliths are composed of calcium carbonate crystals (aragonite), which are de- posited as daily growth increments within a protein matrix. Because of the regularity of crystal deposition, the permanence of the structure, and the dependence of increment thickness on growth rate, analysis of otolith microstructure enables ecologists to infer historic information about both adult and larval fish, including age and growth rates (Karlou-Riga 2000, Ponton et al. 2001), planktonic larval duration (Kawase et al. 1993, Francis 1994, Rogers et al. 2001), and transitions between ontogenetic stages (Sogard 1991, Neuman et al. 2001).

A particularly useful piece of history recorded in otoliths lies in their trace elemental composition. Fish that disperse across gradients in seawater temperature, salinity, or elemental composition effectively 'record' their travels in their hard parts. Trace elements from the surrounding waters substitute for calcium in the calcium carbonate matrix and their concentration reflects differences in the physical characteristics and elemental composition of the water mass in which they were formed (Radtke \& Shafer 1992, Secor et al. 1995, Bath et al. 2000). Larval hard parts formed at the source of production, therefore, potentially carry a natural tag of the larva's site of origin. Fish scientists have examined trace elements present in the otolith to track migration and dispersal patterns and to identify spawning grounds and juvenile nursery habitats (Edmonds et al. 1991, Campana 1999, Jones et al. 1999, Swearer et al. 1999, Thorrold et al. 2001). Information gleaned about recent larval history from this single structure has increased our understanding of the extent of fish larval movement between populations, and of factors influencing local larval and settler success. 
As with fishes, there is a pressing need to understand processes affecting the settlement and survival of invertebrate larvae. For example, the management of commercially important marine invertebrates also requires knowledge about larval dispersal pathways. While DiBacco \& Levin (2000) developed methods to track short-term movements of crab larvae between estuarine and coastal habitats, no effective means to track invertebrate larvae in the plankton from source to settlement exists (Levin 1990). Importantly, larval invertebrates possess mineralized structures, including statoliths, protoconchs, cuttlebones, carapaces, and larval skeletons, that could all potentially record recent dispersal histories. The statolith of molluscs, analogous in structure and function to the otolith, holds particular promise as a dispersal history recorder.

Malacologists have frequently identified the presence of statoliths in molluscan larvae (see Ponder \& Lindberg 1997 for a recent review) and have used statolith microstructure to obtain age and growth information (e.g. Jackson 1994, Bettencourt \& Guerra 2001, Jackson \& Moltschaniwskyj 2001; but see Villanueva 2000 for problems associated with differential increment deposition rates). Furthermore, Radtke (1983) suggested that the isotopic composition of aragonitic squid statoliths can be useful for ecological applications. Statolith structure varies substantially among gastropod families, ranging from multiple statoconia composed of various mineralized elements to single statoliths composed of calcium carbonate. The presence of regularly deposited growth rings in gastropod statoliths (and statoconia) remains largely unexplored (but see Grana-Raffucci \& Appeldorn 1997). In addition, the potential use of the elemental composition of the gastropod statolith for reconstructing dispersal history has not been investigated.

Here, we explore the utility of the mineralized statolith in gastropod molluscs for recording natal sources. First, we describe new methods to isolate larval statoliths in the temperate neogastropod Concholepas concholepas (Bruguière 1789). Next, we examine whether hatch marks delineate the natal core of statoliths from hatched larvae and recent recruits. Finally, we explore whether these mineralized hard parts could serve as natural tags of natal origin by analyzing individual larval statoliths with laser ablation inductively coupled plasma mass spectrometry (LA-ICP-MS) to see if they contain predictably variable levels of trace elements among geographically separated sites in Chile.

Materials and methods. Study organisms: The muricid gastropod Concholepas concholepas is an economically and ecologically important predator in rocky intertidal and subtidal communities along the Peruvian and Chilean coasts of South America (Castilla 1988,
1999). After mating, female C. concholepas deposit egg capsules on rocky substrata (Manríquez \& Castilla 2001). Embryos develop into veliger larvae within the egg capsules for approximately 60 d (Gallardo 1973, Castilla \& Cancino 1976) then hatch as planktonic veliger larvae at $\sim 250 \mu \mathrm{m}$ in maximum shell length (Gallardo 1973). These planktotrophic veliger larvae require roughly $3 \mathrm{mo}$ in the plankton to achieve competent size $(\sim 1600$ to $1800 \mu \mathrm{m})$ and metamorphose (DiSalvo 1988).

Field collections and site characterization: We collected egg capsules of Concholepas concholepas in which encapsulated veliger larvae were either ready to hatch or were within a few days of hatching (hereafter referred to as 'near-hatch larvae'). Near-hatch larvae within egg capsules were readily distinguishable from less developed larvae by their brown color, which was clearly visible through the semi-translucent egg capsules (Manríquez \& Castilla 2001). We collected egg capsules during the months of peak abundance in the field from low rocky intertidal habitats at 3 sites: the Coastal Concession of Minera La Escondida Limitada (copper mine filtering and port plant) at Punta Coloso, in Antofagasta $\left(23^{\circ} 45^{\prime} \mathrm{S}, 70^{\circ} 28^{\prime} \mathrm{W}\right)$, northern Chile, Caleta Coloso in Antofagasta, northern Chile (23 45' 58' S, 70 27' 62" W), and at the Catholic University Marine Protected Area of ECIM (Estación Costera de Investigaciones Marinas) in Las Cruces $\left(33^{\circ} 23^{\prime} \mathrm{S}, 71^{\circ} 42^{\prime} \mathrm{W}\right)$, central Chile (referred to hereafter as Las Cruces). Egg capsules were collected during the lowest tides of May 2001 at Antofagasta and July 2001 at Las Cruces.

Different land use patterns in these areas (i.e. port and copper mining activities near the sites in Antofagasta vs farming and municipal development near Las Cruces) could generate both point source and rainwater runoff inputs that could substantially alter nearshore seawater chemistry. This could result in potentially distinct elemental compositions in developing statoliths. Further, there is a latitudinal gradient in sea surface temperatures in coastal Chile that could also help to generate distinct elemental compositions. Temperatures show a monotonic increase toward lower latitudes (Broitman et al. 2001). To characterize sea surface temperature and precipitation at the sites during the months of collection, we examined 2 National Oceanic and Atmospheric Administration data setsMonthly Climatic Data for the World (NOAA-MCDW) and Mean Monthly Sea Surface Temperature (NOAASST).

Statolith preparation for examination of hatch mark: To explore the possibility of the presence of a 'hatch' mark that would delineate the natal core from posthatching regions of the statolith, we compared the average size of statoliths from near-hatch larvae to that 
of a conspicuous banding mark on the statoliths of post-settlement juveniles. To determine the average diameter $(\mu \mathrm{m})$ of larval statoliths in transition from encapsulated veliger to planktonic veliger (= nearhatch larva), we used Image Pro Plus ${ }^{\mathrm{TM}}$ digital imaging software to measure the statoliths from 5 individuals per brood, measuring 6 broods per site for larvae collected at Las Cruces and at Punta Coloso. We prepared a larval 'squash' slide by gently pressing a cover slip over the drop of water containing larvae. The gentle pressure cracks the shells and makes the statoliths readily visible with a compound microscope at $400 \times$ magnification (Fig. 1a). The statolith images were examined for signs of other growth rings. We dissected out statoliths from juvenile (post-settlement) Concholepas concholepas, mounted them into Crystal Bond $^{\mathrm{TM}}$ resin, and polished them using $1 \mu \mathrm{m}$ diamond grit paper on a polishing wheel to expose the core. The polished statoliths were then examined under a compound microscope at $100 \times$ for evidence of a hatching mark. We measured the diameter of that mark 10 times to generate an average measure for comparison with the diameter of statoliths from the near-hatch larvae.

Statolith preparation for ICP-MS analysis: To determine if statoliths were potential tags of location, we compared element/calcium ratios of statoliths from
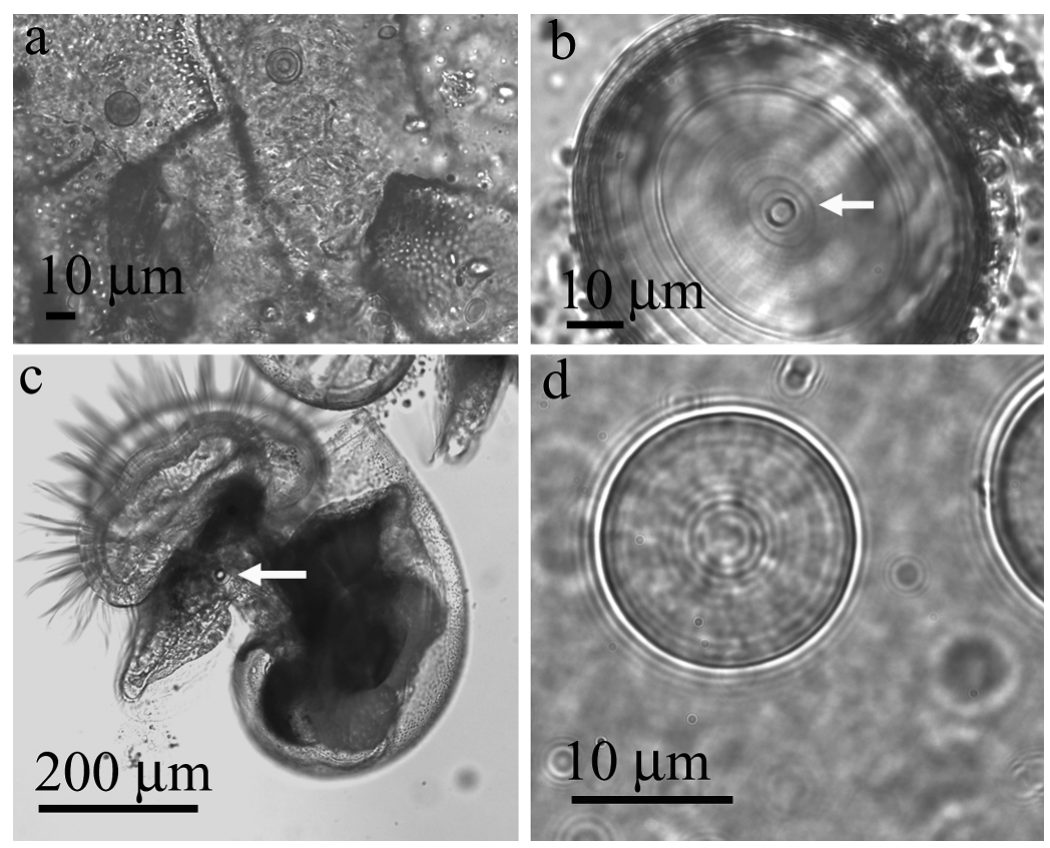

Fig. 1. Statoliths from larvae and recent recruits of 2 species of gastropods: (a) pair of larval Concholepas concholepas statoliths visible through fragments of larval shell; (b) statolith in recently settled C. concholepas individual; (c) nearhatch larva of Kelletia kelletii with statolith visible; (d) statolith from a nearhatch larva of $K$. kelletii with possible daily increments. In (b) arrow indicates a potential 'hatch' mark measuring $11.40 \pm 0.24 \mu \mathrm{m}($ mean $\pm 1 \mathrm{SE}, \mathrm{n}=10)$ in diameter. In (c) the arrow indicates statolith near-hatch larvae of Concholepas concholepas from 3 locations in Chile with differing watershed uses (see above). We analyzed 10 individual statoliths from 10 different broods from Las Cruces and Punta Coloso and 10 individual statoliths from 5 different broods from Caleta Coloso. Only 5 broods were collected at Caleta Coloso due to limited access to that site. Statoliths were extracted from encapsulated veliger larvae by suspending the larvae in an equal volume mixture of $30 \% \mathrm{H}_{2} \mathrm{O}_{2}$ buffered in $0.1 \mathrm{~N} \mathrm{NaOH}$. We statoliths 3 times in ultra pure $\mathrm{H}_{2} \mathrm{O}$ and then petted them onto a clean $20 \times 20 \mathrm{~mm}$ plastic slide rawing off excess water and allowing the remaining to evaporate. Because we analyzed bulk samples were brood, there is a very small chance $(<0.03 \%)$ ve sub-sampled 2 statoliths from the same individual. This would be unlikely to have affected the decrease the amount of variation within a brood. mounted the statoliths for ICP-MS analysis on doublesided tape $\left(\mathrm{Scotch}^{\mathrm{TM}}\right)$. We performed all of the isolation steps in a clean laboratory equipped with class 100 laminar flow hoods. All of the glassware used in the isolation steps was first cleaned using Citranox soap, rinsed 5 times with distilled water (resistivity $>2 \mathrm{M} \Omega$ $\mathrm{cm})$, soaked in $1 \mathrm{~N}$ trace metal grade $\mathrm{HCl}$ overnight, and then rinsed 5 times with ultra pure water (resistivity $>18.1 \mathrm{M} \Omega \mathrm{cm}$ ).

Statoliths were analyzed on a Finnigan Element 2 sector field inductively coupled plasma mass spectrometer (ICP-MS). The abundance of each trace element was expressed as a ratio relative to the amount of calcium to control for differences in amount of material analyzed per sample. We introduced samples into the ICP-MS using a VG-UV microprobe Nd:YAG laser ablation system, frequencyquadrupled to $266 \mathrm{~nm}$ with a nominal beam width of $20 \mu \mathrm{m}$. Each statolith was completely consumed in ablation. The element menu included calcium $(\mathrm{Ca})$, strontium $(\mathrm{Sr})$, barium $(\mathrm{Ba})$, zinc $(\mathrm{Zn})$, and lead $(\mathrm{Pb})$. We calculated detection limits ( $3 \sigma$ in ppm) using $1 \%$ nitric acid instrument blanks: $\mathrm{Sr} 82.5$, Ba 0.1, Zn 2.5, and Pb 0.4. For Sr, Ba, and $\mathrm{Zn}$. The average sample intensity measured $>200$ times the detection limits, with the lowest sample concentration measuring 24 times the detection limit for $\mathrm{Sr}, 135$ times for $\mathrm{Ba}$, and 47 times for $\mathrm{Zn}$, while $\mathrm{Pb}$ samples measured 3 to 18 times the detection 
limits. We compared element/calcium ratios with a nested ANOVA (samples nested within broods within sites).

Results. Site characterization: NOAA-MCDW data for May and July 2001 showed that rainwater runoff input volumes varied substantially between the sites. The monthly total precipitation measured $0 \mathrm{~mm}$ at Antofagasta versus $187 \mathrm{~mm}$ near Las Cruces. At the times of collection, surface waters at Las Cruces, averaging $\sim 14^{\circ} \mathrm{C}$, were approximately $5^{\circ} \mathrm{C}$ colder than at the Antofagasta sites, averaging $\sim 19^{\circ} \mathrm{C}$ (NOAA SST).

Hatch mark: Concholepas concholepas statoliths from near-hatch larvae measured $11.94 \pm 0.01 \mu \mathrm{m}$ at Las Cruces and $11.29 \pm 0.39 \mu \mathrm{m}$ at Punta Coloso. We noted the presence of banding on the statoliths even within unhatched larvae (Fig. 1a). In polished statoliths of competent and recently settled specimens of Concholepas concholepas, we found the presence of multiple concentric rings from the core to the edge. A prominent ring close to the core of the statolith approximated the size of the statoliths at hatching (Fig. 1b), measuring $11.40 \pm 0.24(\mathrm{n}=10) \mu \mathrm{m}$ in diameter.

Microchemistry: For Concholepas concholepas nearhatch larval statoliths from the 3 sites in Chile, we measured the metal/Ca ratios (Table 1) for $\mathrm{Sr}, \mathrm{Zn}, \mathrm{Ba}$, and $\mathrm{Pb}$, and tested whether their concentrations could discriminate among sites (Table 2). Nested ANOVA results showed both among-site and among-brood differences for $\mathrm{Ba} / \mathrm{Ca}$ ratios (both $\mathrm{p}<0.0001$ ). Statolith $\mathrm{Ba} / \mathrm{Ca}$ from Las Cruces was higher than at Caleta Coloso, which was higher than at Punta Coloso (Table 1, Tukey HSD, $\mathrm{p}<0.05)$. Similarly, among-brood and among-site variation for $\mathrm{Pb} / \mathrm{Ca}$ were significant (both $\mathrm{p}<0.0001$ ). In this case, Las Cruces statoliths showed lower $\mathrm{Pb} / \mathrm{Ca}$ than statoliths from the 2 Antofagasta sites (Fig. 2, Table 1, Tukey HSD, $\mathrm{p}<0.05)$. Zn/Ca in statoliths also exhibited significant among-brood variation $(\mathrm{p}<0.0001)$ and among-site variation $(p<0.0001)$. Statoliths from Las Cruces and Punta Coloso showed significantly lower Zn/Ca than statoliths from Caleta Coloso (Fig. 2, Table 1, Tukey HSD, $\mathrm{p}<0.05)$. Sr/Ca in statoliths did not vary significantly among broods $(p=0.5251)$ or sites $(p=0.7943)$.

Discussion. Our results demonstrate the presence of statoliths in Concholepas concholepas from encapsulated larval to post metamorphic stages. The presence of an apparent natal ring marking the ontogenetic transition into the plankton makes it possible to identify the portion of the statolith formed at
Table 1. Trace element abundance expressed as ratios to $\mathrm{Ca}$ in larval statoliths from 3 sites. $\mathrm{Sr} / \mathrm{Ca}$ and $\mathrm{Zn} / \mathrm{Ca}$ are $\mathrm{mmol} \mathrm{mol}{ }^{-1}$. Ba/Ca and $\mathrm{Pb} / \mathrm{Ca}$ are $\mu \mathrm{mol} \mathrm{mol}^{-1}$. Values shown are the average $\pm 1 \mathrm{SE}$

\begin{tabular}{|lrrr|}
\hline $\begin{array}{l}\text { Metal/ } \\
\text { Calcium }\end{array}$ & Las Cruces & Punta Coloso & Caleta Coloso \\
\hline $\mathrm{Sr} / \mathrm{Ca}$ & $12.82 \pm 0.24$ & $12.57 \pm 0.27$ & $12.76 \pm 0.46$ \\
$\mathrm{Zn} / \mathrm{Ca}$ & $1.37 \pm 0.03$ & $1.43 \pm 0.04$ & $2.45 \pm 0.11$ \\
$\mathrm{Ba} / \mathrm{Ca}$ & $35.96 \pm 1.28$ & $12.60 \pm 0.48$ & $19.49 \pm 0.55$ \\
$\mathrm{~Pb} / \mathrm{Ca}$ & $1.33 \pm 0.11$ & $4.1 \pm 0.18$ & $5.04 \pm 0.21$ \\
\hline
\end{tabular}

the larva's natal site. We noted the presence of additional banding on the statoliths of both juvenile individuals and unhatched larvae (Fig. 1a,b) that could indicate possible daily increments. Statoliths in another neogastropod species, Kelletia kelletii, from coastal California, also exhibit increments that could be deposited daily in nearhatch larvae (Fig. 1c,d, and see Zacherl 2002). These combined data suggest that the gastropod statolith may be useful for aging and growth rate studies, but further investigation into the timing of ring production is required.

Our trace elemental analyses of statoliths from 3 sites provide preliminary evidence suggesting that statoliths can function as natal tags. The trace element data demonstrate that a multi-element approach (in this case using just $\mathrm{Pb} / \mathrm{Ca}$ and $\mathrm{Zn} / \mathrm{Ca}$ ) can yield complete discrimination between Las Cruces and the 2 Antofagasta sites as well as clustering of broods by site between the 2 Antofagasta locations (Fig. 2).

Table 2. Concholepas concholepas. Nested ANOVA comparing trace element concentrations in larval statoliths between sites. Samples were nested within broods; broods were nested within sites

\begin{tabular}{|c|c|c|c|c|c|c|}
\hline $\mathrm{Me} / \mathrm{Ca}$ & Source & SS & df & MS & $F$ ratio & $\mathrm{p}$ \\
\hline \multirow[t]{4}{*}{$\mathrm{Ba} / \mathrm{Ca}$} & Site & 14518.3 & 2 & 7259.16 & 15.46 & $<0.0001$ \\
\hline & Brood (site) & 10327.8 & 22 & 469.44 & 24.15 & $<0.0001$ \\
\hline & Sample (brood, site) & 4373.2 & 225 & 19.44 & & \\
\hline & Total & 29219.3 & 249 & & & \\
\hline \multirow[t]{4}{*}{$\mathrm{Zn} / \mathrm{Ca}$} & Site & 44.1 & 2 & 22.07 & 22.11 & $<0.0001$ \\
\hline & Brood (site) & 21.9 & 22 & 0.99 & 6.60 & $<0.0001$ \\
\hline & Sample (brood, site) & 34.0 & 225 & 0.15 & & \\
\hline & Total & 100.1 & 249 & & & \\
\hline \multirow[t]{4}{*}{$\mathrm{Sr} / \mathrm{Ca}$} & Site & 3.2 & 2 & 1.61 & 0.23 & 0.7943 \\
\hline & Brood (site) & 152.5 & 22 & 6.932 & 0.95 & 0.5251 \\
\hline & Sample (brood, site) & 1636.0 & 225 & 7.27 & & \\
\hline & Total & 1791.7 & 249 & & & \\
\hline \multirow[t]{4}{*}{$\mathrm{Pb} / \mathrm{Ca}$} & Site & 614.0 & 2 & 307.02 & 42.91 & $<0.0001$ \\
\hline & Brood (site) & 157.4 & 22 & 7.16 & 4.25 & $<0.0001$ \\
\hline & Sample (brood, site) & 379.1 & 225 & 1.68 & & \\
\hline & Total & 1150.5 & 249 & & & \\
\hline
\end{tabular}




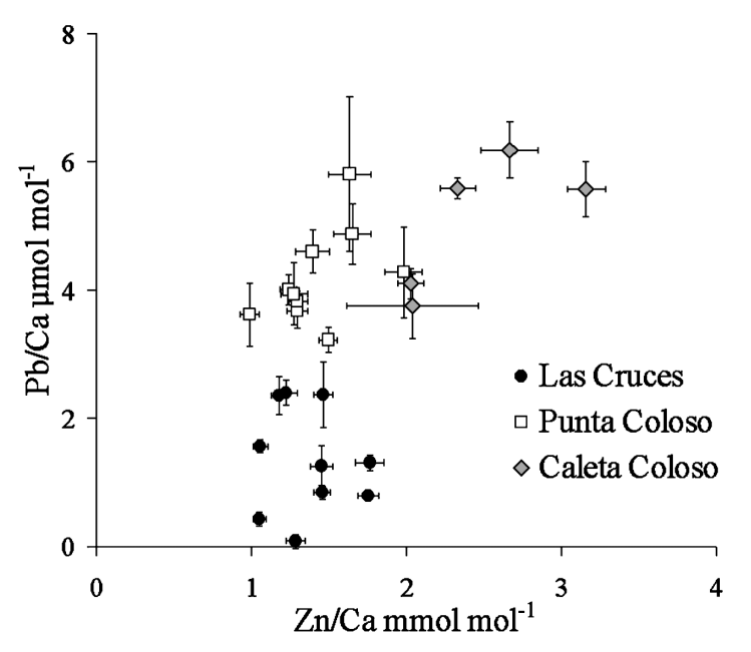

Fig. 2. $\mathrm{Pb} / \mathrm{Ca}$ versus $\mathrm{Zn} / \mathrm{Ca}$ for Concholepas concholepas larval statoliths from Las Cruces, Caleta Coloso and Punta Coloso. Points shown are averages $\pm 1 \mathrm{SE}$ per brood

The site-specific elemental compositions in Concholepas concholepas statoliths could have a number of potential causes, including variation in elemental concentrations in seawater, seawater temperature, genetics, salinity, and variable precipitation rate (see Campana 1999 for a review and see below for possible confounding factors). Assignment of the exact mechanisms controlling the incorporation rates of the elements we measured is uncertain in the absence of a detailed study of the physical-chemical characteristics of the seawater at each collection site, which goes beyond the scope of this study. However, enough is known about the physical setting to assess whether the patterns we observed are consistent with factors influencing elemental incorporation rates. For example, $\mathrm{Ba} / \mathrm{Ca}$ was most elevated at Las Cruces and lower at the Antofagasta sites. Ba in seawater follows a nutrientlike distribution; its main sources are river runoff and upwelling of Ba-rich deep water (Chan et al. 1977). Ba incorporates into aragonitic fish otoliths in proportion to Ba seawater concentration (Bath et al. 2000), and elevated Ba in both mollusc shells (Stecher 1996) and coral aragonite skeletons (Lea et al. 1989) has been associated with periods of intense nutrient flux and upwelling, respectively. Further, Zacherl (2002) demonstrated that Ba incorporation into Kelletia kelletii statoliths increases with decreasing temperature. Since the seawater near Las Cruces was colder and more influenced by nutrient rich rainwater runoff, the observed $\mathrm{Ba} / \mathrm{Ca}$ pattern in field-collected larval statoliths was consistent with both the physical characterization of the sites as well as current knowledge about factors influencing Ba incorporation into biogenic aragonite.
Similarly, $\mathrm{Pb}$ shows a scavenged profile in the world's oceans; it is enriched in surface waters and depleted with increasing depth. Of the elements measured, $\mathrm{Pb}$ is most associated with industrial pollution, such as would result from point source copper mining effluent at the Antofagasta sites. Richardson et al. (2001) measured elevated Pb concentrations in mussel shells near known point sources of $\mathrm{Pb}$ pollution. The elevated $\mathrm{Pb}$ observed in Concholepas concholepas statoliths from the Antofagasta sites is consistent with this information.

Other mechanisms might also explain the observed patterns and could invalidate the use of these statoliths as natal tags. For example, samples were collected only during May at Antofagasta and only during July at Las Cruces. We chose these times so we would collect egg masses during the maximal egg production period at each site. This method introduces a possible confounding factor. If there is large enough temporal variation in elemental composition of statoliths within a site, the pattern we observed could have been generated by temporal fluctuations in the physical or chemical characteristics of seawater across the entire region as opposed to being generated by variance in these characteristics over space.

It is not necessary to fully understand the mechanisms generating differences among regions to utilize this tool as a natal tag of origin. However, it is necessary to demonstrate stable spatial variation in elemental composition of the natal tag over a time period of interest. Using this technique for identifying the natal origin of post-settlement individuals requires sampling sites over the geographic scale of the species' range to measure the extent and pattern of spatial variation in trace elemental composition. Further, within each site, enough broods must be sampled to ensure that variance within a site is fully represented. Third, we need to examine temporal variation in statolith chemistry within sites since this tool will be most effective if variation among sites in trace elemental composition exceeds temporal variation within a site. Alternately, the problem of temporal variation within sites can be addressed by sampling at the sites of origin during the appropriate time corresponding to the birth of the subsequently sampled recruits.

It is possible to expand the element menu to include other trace elements (such as $\mathrm{Li}, \mathrm{Mg}, \mathrm{Mn}$, and Fe) that are detectable in fish otoliths and that substitute into the calcium carbonate matrix as a function of temperature and concentration in seawater (Campana 1999). This expanded menu may enable a multi-element analysis that could yield complete discrimination among all sites.

To implement this technique, incoming settlers can be collected, their statoliths removed, and natal por- 
tions of the statolith can be identified using the 'hatch' mark. This natal core can then be ablated using an ablation system with a nominal beam width whose resolution is smaller than the diameter of the natal core (e.g. $5 \mu \mathrm{m}$ beam width, see Thorrold \& Shuttleworth 2000), and the resultant elemental signal could elucidate source population information.

In Concholepas concholepas larval statoliths, differences in trace elemental concentration between sites might be exploitable as 'natal tags' that effectively mark each maturing larva with a site-specific signal (Fig. 2). The use of the elemental signals in larval statoliths as tags of source could be an important tool for examining connectivity between marine populations.

Recently, Manríquez \& Castilla (2001) demonstrated the importance of marine protected areas in Central Chile as rich larval production sites for Concholepas concholepas. However, to date, the spatial scale of the effective seeding process remains unknown. Where do larvae produced within marine protected areas settle? Effective planning for the sizes and locations of new marine reserves and protected areas requires an understanding of connectivity between populations and identification of source populations for incoming larvae. The existence of distinguishable elemental concentrations in C. concholepas larval statoliths from 2 areas in Chile suggests that natal tags could distinguish statoliths produced at different sites, and hence, potentially identify source populations for settling larvae.

Other invertebrate phyla (e.g. ctenophores, cnidarians, nemerteans, echinoderms, and crustaceans) build mineralized hard parts that could be useful for reconstructing larval histories. Given the pressing need to preserve marine biodiversity and effectively manage invertebrate fishery populations, the statolith as recorder of natal source represents an exciting avenue for understanding the processes affecting the dispersal and settlement patterns of marine larvae.

Acknowledgements. This is contribution no. 94 of the Partnership for Interdisciplinary Studies of Coastal Oceans (PISCO): a long-term ecological consortium funded by the David and Lucile Packard Foundation. Support was also received from grants by the Andrew Mellon Foundation to Pontificia Universidad Católica de Chile and to S.D.G. This study is part of D.C.Z.'s PhD dissertation. She thanks Sigma $\mathrm{Xi}$, and the Lerner-Gray Foundation for financial support and $\mathrm{S}$. Swearer for providing valuable training and guidance. P.H.M. and J.C.C. thank M. Cerda and C. Pacheco for field assistance in Antofagasta and Minera Escondida Ltda for logistic support. A. Shanks is acknowledged for suggesting that P.H.M. and J.C.C. study Concholepas concholepas statoliths. P.H.M. gratefully acknowledges B. Broitman for his warm welcome to Isla Vista, Santa Barbara, California, USA. This manuscript was finished during the tenure of FONDAPFONDECYT 1501-0001 to the Center for Advanced Studies in Ecology and Biodiversity, Chile.

\section{LITERATURE CITED}

Bath GE, Thorrold SR, Jones CM, Campana SE, McLaren JW, Lam JWH (2000) Sr and Ba uptake in aragonitic otoliths of marine fish. Geochim Cosmochim Acta 64:1705-1714

Bettencourt V, Guerra A (2001) Age studies based on daily growth increments in statoliths and growth lamellae in cuttlebone of cultured Sepia officinalis. Mar Biol 139: 327-334

Broitman BR, Navarette SA, Smith F, Gaines SD (2001) Geographic variation of southeastern Pacific intertidal communities. Mar Ecol Prog Ser 224:21-34

Caley MJ, Carr MH, Hixon MA, Hughes TP, Jones GP, Menge BA (1996) Recruitment and the local dynamics of open marine populations. Annu Rev Ecol Syst 27:477-500

Campana SE (1999) Chemistry and composition of fish otoliths: pathways, mechanisms and applications. Mar Ecol Prog Ser 188:263-297

Castilla JC (1988) Una revisión bibliográfica (1980-1988) sobre Concholepas concholepas (Gastropoda, Muricidae): problemas pesqueros y experiencias de repoblación. Biol Pesq 17:9-19

Castilla JC (1999) Coastal marine communities: trends and perspectives from human-exclusion experiments. Trends Ecol Evol 14:280-283

Castilla JC, Cancino J (1976) Spawning behaviour and egg capsules of Concholepas concholepas (Mollusca: Gastropoda: Muricidae). Mar Biol 37:255-263

Castilla JC, Defeo O (2001) Latin American benthic shellfisheries: emphasis on co-management and experimental practices. Rev Fish Biol Fish 11:1-30

Chan LH, Drummond D, Edmund JM, Grant B (1977) On the barium data from the Atlantic GEOSECS expedition. Deep-Sea Res 24:613-649

Crowder LB, Lyman SJ, Figueira WF, Priddy J (2000) Sourcesink population dynamics and the problem of siting marine reserves. Bull Mar Sci 66:799-820

DiBacco C, Levin LA (2000) Development and application of elemental fingerprinting to track the dispersal of marine invertebrate larvae. Limnol Oceanogr 45(4):871-880

DiSalvo LH (1988) Observations on the larval and post-metamorphic life of Concholepas concholepas (Bruguière, 1789) in laboratory culture. Veliger 30:358-368

Edmonds JS, Caputi N, Morita M (1991) Stock discrimination by trace-element analysis of otoliths of orange roughy (Hoplostethus atlanticus), a deep-water marine teleost. Aust J Mar Freshw Res 42:383-389

Francis MP (1994) Duration of larval and spawning periods in Pagrus auratus (Sparidae) determined from otolith daily increments. Environ Biol Fishes 39(2):137-152

Gaines SD, Gaylord B, Largier JL (in press) Avoiding current oversights in marine reserve design. Ecol Appl

Gallardo C (1973) Desarrollo intracapsular del Concholepas concholepas (Bruguière) (Gastropoda Muricidae). Mus Nac Hist Nat Publ Ocas (Santiago de Chile) 16:3-16

Grana-Rafucci FA, Appeldorn RS (1997) Age determination of larval strombid gastropods by means of growth increment counts in statoliths. Fish Bull 95(4):857-862

Jackson GD (1994) Application and future potential of statolith increment analysis in squids and sepioids. Can J Fish Aquat Sci 51:2612-2625

Jackson GD, Moltschaniwskyj NA (2001) The influence of ration level on growth and statolith increment width of the tropical squid Sepioteuthis lessoniana (Cephalopoda: Loliginidae): an experimental approach. Mar Biol 138: 819-825

Jones GP, Milicich MJ, Emslie MJ, Lunow C (1999) Self- 
recruitment in a coral reef fish population. Nature 402: 802-804

Karlou-Riga C (2000) Otolith morphology and age and growth of Trachurus mediterraneus (Steindachner) in the Eastern Mediterranean. Fish Res 46(1-3):69-82

Kawase H, Mochioka N, Nakazono A (1993) Otolith increment formation and planktonic larval duration of a temperate damselfish, Chromis-notatus notatus. Jpn J Ichthyol 40(3):377-380

Lea DW, Shen GT, Boyle EA (1989) Coralline barium records temporal variability in equatorial Pacific upwelling. Nature 340:373-376

Levin LA (1990) A review of methods for labeling and tracking marine invertebrate larvae. Ophelia 32:115-144

Manríquez PH, Castilla JC (2001) Significance of marine protected areas in central Chile as seeding grounds for the gastropod Concholepas concholepas. Mar Ecol Prog Ser 215:201-211

Neuman MJ, Witting DA, Able KW (2001) Relationships between otolith microstructure, otolith growth, somatic growth and ontogenetic transitions in two cohorts of windowpane. J Fish Biol 58(4):967-984

Ponder WF, Lindberg DR (1997) Towards a phylogeny of gastropod molluscs: an analysis using morphological characters. Zool J Linn Soc 119:83-265

Ponton D, Mol JH, Panfili J (2001) Use of otolith microincrements for estimating the age and growth of young armoured catfish Hoplosternum littorale. J Fish Biol 58(5): $1274-1285$

Radtke RL (1983) Chemical and structural characteristics of statoliths from the short-finned squid Illex illecebrosus. Mar Biol 76:47-54

Radtke RL, Shafer DJ (1992) Environmental sensitivity of fish otolith microchemistry. Aust J Mar Freshw Res 43(5): 935-951

Richardson CA, Chenery SRN, Cook JM (2001) Assessing the history of trace metal $(\mathrm{Cu}, \mathrm{Zn}, \mathrm{Pb})$ contamination in the North Sea through laser ablation ICP-MS of horse mussel

Editorial responsibility: Lisa Levin (Contributing Editor), La Jolla, California, USA
Modiolus modiolus shells. Mar Ecol Prog Ser 211:157-167 Rogers JS, Hare JA, Lindquist DG (2001) Otolith record of age, growth, and ontogeny in larval and pelagic juvenile Stephanolepis hispidus (Pisces:Monacanthidae). Mar Biol 138(5):945-953

Secor DH, Henderson-Arzapalo A, Piccoli PM (1995) Can otolith microchemistry chart patterns of migration and habitat utilization in anadromous fishes? J Exp Mar Biol Ecol 192(1):15-34

Sogard SM (1991) Interpretation of otolith microstructure in juvenile winter flounder (Pseudopleuronectes americanus) ontogenetic development, daily increment validation, and somatic growth relationships. Can J Fish Aquat Sci 48(10): 1862-1871

Stecher HA III, Krantz DE, Lord CJ III, Luther GW III, Bock KW (1996) Profiles of strontium and barium in Mercenaria mercenaria and Spisula solidissima shells. Geochim Cosmochim Acta 60:3445-3456

Swearer SE, Caselle JE, Lea DW, Warner RR (1999) Larval retention and recruitment in an island population of a coral reef fish. Nature 402:799-802

Thorrold SR, Shuttleworth S (2000) In situ analysis of trace elements and isotope ratios in fish otoliths using laser ablation sector field inductively coupled plasma mas spectrometry. Can Fish Aquat Sci 57:1232-1242

Thorrold SR, Latkoczy C, Swart PK, Jones CM (2001) Natal homing in a marine fish metapopulation. Science 29: 297-299

Villanueva R (2000) Differential increment-deposition rate in embryonic statoliths of the loliginid squid Loligo vulgaris. Mar Biol 137:161-168

Warner RR, Swearer SE, Caselle JE (2000) Larval accumulation and retention: Implications for the design of marine reserves and essential fish habitat. Bull Mar Sci 66: 821-830

Zacherl DC (2002) Dispersal of larval invertebrates: use of natural tags to identify natal origins. $\mathrm{PhD}$ thesis, University of California, Santa Barbara

Submitted: April 15, 2002; Accepted: October 28, 2002 Proofs received from author(s): February 7, 2003 